\title{
J. C. Harrington Medal in Historical Archaeology
}

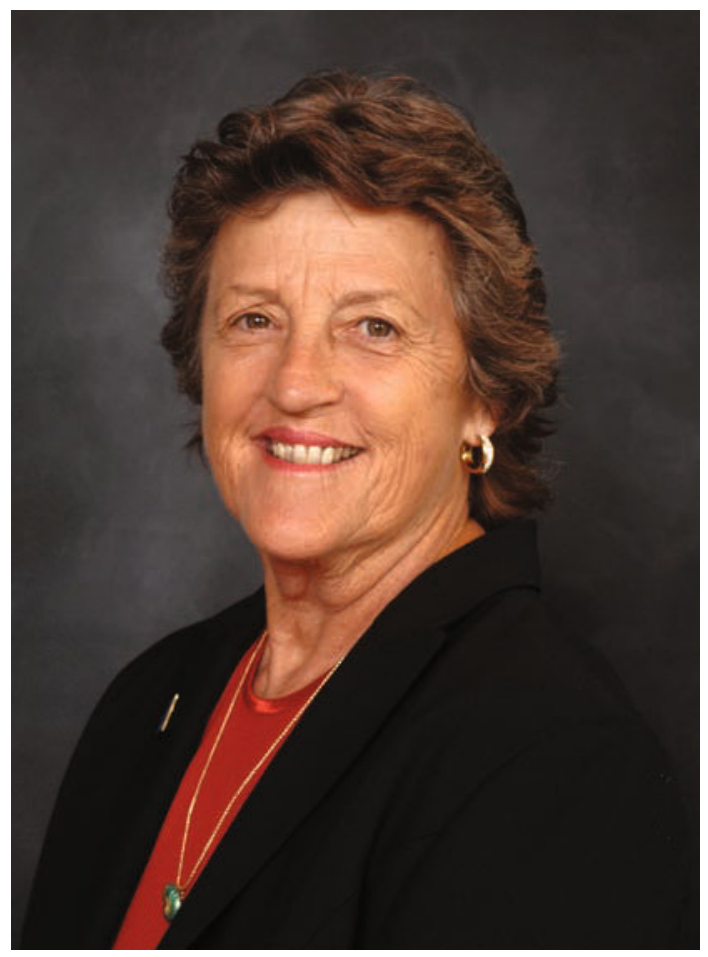

\section{Judith Ann Bense}

Judy Bense tells all who will listen that she was a walk-on at the University of West Florida (UWF) in 1980. The university in that year was barely 15 years old, had fewer than 5,000 students, and did not employ an archaeologist or anthropologist in any capacity. With characteristic optimism, Dr. Bense saw this as prerequisite for success. With tenacity and growing political acuity she built archaeology into a signature program for the university, and with great energy and passion reached out beyond west Florida to make significant contributions to archaeology and historic preservation in Florida, nationally, and through an organization that she truly loves, the Society for Historical Archaeology.

Although she was born in Morristown, New Jersey, Judith Ann Bense has long called west Florida home. The promise of a successful dairy farm caused parents Bud and Bette to move their two young children to Panama City, Florida in 1951 (a third child was born later in Florida). Family trips to historical state parks in the region may have been what sparked Judy's early interest in history and archaeology, proclaimed as early as eight years of age. She attended Panama City's Bay High School (the "Fighting Tornadoes") and graduated in 1963. For reasons that have eluded those involved, an unusually large number of Bay High graduates have gone on to become practicing archaeologists, including Jay Johnson (University of Mississippi), the late George Hicks (formerly chair of Anthropology, Brown University), Bennie Keel (National Park Service, retired), Keith Stephenson (University of South Carolina), Louis Tesar (Florida Bureau of Archaeological Research), and Martha Zierden (Charleston Museum). 
On graduating from high school, Judy went straight on to college at Florida State University (FSU) intent on studying archaeology. At FSU she discovered that archaeology was a part of anthropology. She studied under David S. Phelps, who chaired her thesis work on the Late Woodland shell ring, Bird Hammock, in Wakulla County, Florida. Phelps later moved to East Carolina University and was instrumental in the search for Sir Walter Raleigh's Lost Colony. Also at FSU was Hale G. Smith who had founded the department in 1950 and was director of the historical archaeology program. His work on Spanish colonial sites in Florida predicted some of Judy's later work: She says of this, "I wound up chasing [him] all over Pensacola and northwest Florida because he did all these Spanish sites."

Judy completed her masters in March of 1969 and immediately took her first paid job in archaeology, working for six months as a crew chief for B. Calvin Jones of the Florida Division of Archives, History, and Records Management (predecessor of the Florida Division of Historical Resources) on the Interstate 10 survey through Tallahassee. With legendary intuition, Jones led the crew to several Spanish missions within the right-of-way. The crew consisted of day labor drawn mostly, as Judy recalls, from "Vietnam veterans in various stages of being out of the jungle and being shot at. They were fine."

From the I-10 project Judy went directly to doctoral study at Washington State University, arriving there in the fall of 1969. While an undergraduate at FSU, Judy had minored in geology, and she took that interest with her to Washington State to study geoarchaeology with Richard Daugherty, who was department chair, and the late Frank C. Leonhardy who served as her major professor. Her dissertation, The Cascade Phase: A Study in the Effect of the Altithermal on a Cultural System, utilized site data from a decade of excavations conducted along the lower Snake River which was being impounded for hydroelectric power. This huge compliance project was winding down when Judy arrived in Pullman, Washington, and she used site data to examine the effects of prehistoric climate change on the local Native American cultures.

At the time Judy completed her Ph.D. in 1972 when she was 27 years old, she was faced with a crossroads defined by family needs and by serious personal uncertainties about the culture of academic archaeology. Her father had passed away in 1967 shortly after seeing Judy receive her bachelor's from FSU, and her mother died suddenly in 1972 three months before she completed her Ph.D. With both parents gone, she felt the need to return to Florida to care for her elderly grandmother and great aunt, and be near her two younger brothers (Chris and Allan) who were immersed in their college educations. With this, and with a growing discontent with the covertly individualistic, competitive nature of archaeological scholarship that she had witnessed at major universities on opposite sides of the continent, Dr. Bense hung her new diploma at the family farm in Panama City. There she turned her attention away from academia and toward what she perceived to be a more refreshing, overtly competitive yet honest business world. For five years she focused on making a living and providing support for her family with a business focused on horses and dogs.

Her decision to put her academic training aside came at a time when the profession of archaeology in the United States was seated largely in major research universities and in government agencies at the federal and state levels. In Judy's intervening "horse and dog" years, the landscape of professional archaeology changed dramatically.

For an individual who proclaimed her desire to be an archaeologist at the age of eight, it is perhaps less than surprising that Judy did not stay away long. In 1977 she accepted an appointment as adjunct assistant professor at the Panama City Center of UWF and taught upper-level undergraduate classes at night. In the summer of 1977 she taught a field school at the Kings Point site on St. Andrews Bay. This was the first archaeological field school ever taught at UWF. One of her students was Bay High graduate Martha Zierden.

Of pivotal importance in Judy's career was attendance at the 42nd annual meeting of the Society for American Archaeology in New Orleans in the spring of 1977. There she reconnected with the Washington State crowd, including Bennie Keel, Leslie Wildesen, Ruthann Knudson, and Gerald Schroedl. They filled her in on the sea change that had swept American archaeology since 1972. In 
1971, President Nixon had signed Executive Order 11593 that required federal agencies to ensure that historical and archaeological properties under their jurisdiction were preserved. Among other results, this executive order caused agencies to undertake major resource inventories and National Register evaluations of sites on property they managed. In 1974 the U.S. Congress passed the Moss-Bennett Act (Public Law 93-291) which amended and expanded the Reservoir Salvage Act of 1960 and required all federal undertakings to consider impacts to historical and archaeological properties. These developments established the groundwork for today's cultural resource management and by 1977 had created an incredible need for professional archeologists available to go to work. With this great influx of development- and management-based projects and a limited number of unaffiliated Ph.D.'s, Judy was well positioned to take advantage of this uncertain yet heady new world.

Bennie Keel, one of the many products of Bay High School, and a graduate of FSU and Washington State, had long been an acquaintance of Judy's. In 1977 he was chief of the National Park Service's Interagency Archaeological Services in Atlanta, and was well positioned to help Judy reenter archaeology on a full-time basis. He immediately set up Dr. Bense with a contract for a cultural resource reconnaissance of the St. Marks National Wildlife Refuge along the Apalachee Bay on the Florida Gulf Coast. This project was her first contract in archaeology, and fieldwork was undertaken during the semester break in the winter of 1977-1978. Bennie followed this project with a contract for a small mitigation project in Mobile, Alabama, and a large testing project of 58 sites along the Tennessee-Tombigbee Waterway in Mississippi.

"Tenn-Tom," as it was affectionately known, took Judy away from Panama City and into the business of professional archaeology, but this project also landed her back at a large research university. In 1978 she became senior research archaeologist at the Office of Archaeological Research, University of Alabama. At Alabama she completed the testing project for Interagency Archaeological Services and then undertook additional work on Tenn-Tom for the Mobile District of the U.S. Army Corps of Engineers. These were massive projects, involving extended periods of field work and large crews of both anthropology bachelor's graduates and unskilled laborers. But at Alabama she found the same negative internal atmosphere that she had experienced at FSU and Washington State, and liked it no better the third time around. She did not stay.

Dr. Bense looks back at her decision to leave Alabama as the biggest crossroads of her career. She wanted to teach and do research but she was not interested in doing this at a large university with an established program in archaeology with all its internal baggage and attitudes. She became determined to find a university setting where she could build a truly collegial team focused on the concept that students were the priority. She believed that if she could not find this place soon she would leave archaeology again, for good. She had come to realize that the only way to accomplish this dream was to find a smaller university setting where archaeology was non-existent - a place without the baggage, existing relationships, expectations, and politics that she had repeatedly seen at major research universities.

In 1979 Dr. Bense visited UWF and set the groundwork for a move to Pensacola. In exchange for bringing her Tennessee-Tombigbee contracts to UWF, the university agreed to establish a new anthropology bachelor's degree program with two faculty lines. From Judy's perspective, UWF was the perfect location to build a program that was based on teamwork and focused on students. The key attraction of UWF was, in fact, its lack of archaeology or anthropology; there was no status quo, no expectations, and no personal agendas to navigate. In 1980 Judy became a walk-on at the University of West Florida. The qualities that attracted her to UWF of course also presented immediate challenges as she sought to establish an archaeological research program on a campus not at all prepared for this type of endeavor.

In these early days of CRM, however, things were different, and as part of the contract came federal infrastructure support to purchase capital equipment. A new curation facility was also erected on campus funded by project overhead. The research unit was called variously the Office of Archaeological Research, the Office of Contracts and Grants, the West Florida Institute of Archaeology, and finally, the UWF Archaeology Institute. This building remained home to the 
archaeological research program for 17 years, and now houses the university printing office. In the 1990s, a modern new building with exhibit, lab, classroom, and office space was constructed to house the UWF Archaeology Institute. It sits prominently at the main entrance to campus.

While work associated with the Tennessee-Tombigbee project lasted through 1984 and established archaeology at UWF, with this massive project ending Dr. Bense immediately began to cast about for opportunities, which were not long in coming. This work included contracts with utilities and developers, and state historic preservation grants.

The year 1984 brought two projects that anchored the future of archaeology at UWF. In that year, construction of a new city hall building began in downtown Pensacola. Reports of the discovery by collectors and looters of amazing relics of the town's forgotten colonial history soon made their way to Judy, and she and her very first archaeology students salvaged some of what was quickly being destroyed. This experience revealed to Dr. Bense the vulnerability of the pristine archaeological deposits right in her front yard, and the high level of ignorance about their existence among well-educated and well-meaning community leaders. She immediately realized public and city officials needed to be educated about the importance of what was underground and how easily it could be lost. The presence of a new archaeology office on campus paved the way for years of scientific excavation within downtown Pensacola as urban renewal came to town. During this period the city and its residents came to realize that the remains of Pensacola's Spanish and British colonial history were well preserved just inches below the surface throughout much of downtown.

The massive urban archaeology work kicked off by the City Hall project brought Dr. Bense face to face with Spanish and British colonial archaeology. A career that previously had focused on prehistory was rapidly transformed to one anchored by a deep interest in the archeology of the Spanish colonial period. Dr. Bense refers to this immersion in historical archaeology as her second Ph.D., and it was the point at which she began to self-identify as an historical archaeologist.

In 1984 Dr. Bense also made a proposal to Gulf Power that paved the way for public archaeology at UWF. Construction of the new Gulf Power headquarters building had been announced for a piece of land east of downtown Pensacola - the location of a Middle Woodland period site and the historic African American neighborhood known as "Hawkshaw." Although it was under no obligation to do so, Judy proposed that Gulf Power conduct archaeological and historical investigations prior to construction, and make the results accessible to the public through programs, publications, and exhibits. Gulf Power agreed, and for the next two years the archaeology at Hawkshaw was very much in the public eye. In 1986, Gulf Power and Dr. Bense received the Department of the Interior's National Public Service Award in recognition of the Gulf Power project at Hawkshaw. This was the first time this award was bestowed for archaeology.

The visibility that Hawkshaw and the downtown projects brought to archaeology and the UWF illustrated to Judy the importance of the public in advancing archaeology, and as a consumer of archaeological research. It was at this point that she embraced what today is known as "public archaeology" (though in the 1980s this term referred to what we today call cultural resource management), and it has become an essential component of UWF archaeology, leading ultimately to the creation of the Florida Public Archaeology Network in 2005.

Over the next decades, archaeology in downtown Pensacola (the 1754-1763 Presidio San Miguel de Panzacola, the 1763-1781 British Fort of Pensacola, and the 1781-1821 Spanish Town of Pensacola) came to be expected, and public interest in, and knowledge of Pensacola's colonial heritage grew. Dr. Bense also undertook research on the well preserved 1698-1722 Spanish Presidio Santa María de Galve located on Naval Air Station Pensacola between 1995 and 1998; and the 1722-1752 Presidio Isla de Santa Rosa located on Gulf Islands National Seashore (first investigated by Hale Smith in 1964) between 2002 and 2004. These projects have formed the basis of Dr. Bense's research, and have also provided experience and thesis projects for innumerable undergraduate and graduate students.

Maritime archaeology at UWF can be traced back to 1989, when State Underwater Archaeologist Roger Smith taught a class on weekends during the spring semester, followed by UWF's first maritime archaeology field school that summer. The site investigated was the Dead Man's Island 
wreck, which had been reported during a terrestrial survey the previous summer. Investigated were the remains of a late-18th-century British sloop.

In the early 1990s, Roger Smith returned to Pensacola to conduct the Pensacola Shipwreck Survey for the Bureau of Archaeological Research (BAR). This survey resulted in the discovery of a 16th-century Spanish shipwreck in $12 \mathrm{ft}$. of water off downtown Pensacola's shoreline. The "Emanuel Point" wreck was one of several sunk in a hurricane in 1559, one month after the arrival of the settlement expedition commanded by don Tristán de Luna y Arellano. The BAR-conducted initial investigations of this wreck in the mid-1990s, and in 1997 a partnership between BAR and UWF led to the continued excavation of this wreck. Well-preserved remains of this vessel and fragments of its cargo were discovered during this work. Excavations were watched closely by an enthralled public and media.

The success of the Emanuel Point project convinced Dr. Bense to take the underwater heritage of Pensacola Bay under her wing and inspired her to add maritime archaeology to the research and academic program at UWF. In 1999, work was begun by UWF on what are probably the remains of the Nuestra Señora del Rosario y Santiago Apostol, a large frigate and former flagship of the Spanish Windward Fleet which had patrolled Gulf and Caribbean waters. The Rosario was lost in a 1705 hurricane shortly after arriving at Presidio Santa María de Galve (1698-1719), near the modern city of Pensacola, Florida. From these beginnings the UWF's graduate program, which offers maritime archaeology, has gained national respect in terms of research, public outreach, and student training.

Concurrent with the development of local archaeological research and the growing importance of public archaeology at UWF was the development of the academic program. In 1979 Dr. Bense had helped to design the original anthropology curriculum. In 1981, cultural anthropologist Terry J. Prewitt joined the faculty and assisted Judy in teaching classes for an undergraduate degree in anthropology in a department that was partnered with sociology (and chaired by a sociologist), and which, over the years, variously included other disciplines such as geography and environmental science. In 1983 Judy became visiting assistant professor of anthropology and in 1985 entered the tenure track as assistant professor. In that same year she was appointed as director of the Archaeology Institute. Judy received tenure in 1988 and became a full professor in 1994.

Recognizing that a graduate program in anthropology was unlikely as long as sociology controlled the department, Dr. Bense worked with Dr. William Coker, chair of the Department of History, to create a master's program in historical archaeology within that department. Dr. Bense taught the anthropology graduate classes in this program which was established in 1991 and had its first graduate in 1996.

In 2000, Dr. Bense became chair of the Department of Sociology and Anthropology. The following year, sociology was dropped from the department name, recognizing the much diminished role of sociology in the curriculum. In 2002 a master's in anthropology and in historical archaeology was established within the department.

In 2004 and 2005, Dr. Bense and others worked to establish legislation and obtain funding for the Florida Public Archaeology Network (FPAN). This program is housed at UWF and operates regional public archaeology centers throughout Florida, where public archaeologists are charged with raising awareness of Florida archaeology through public outreach, work with local government, and assistance to the Florida Division of Historical Resources. Together, the successes of the Archaeology Institute, Department of Anthropology, and FPAN have led to the recognition of anthropology as a signature program of the UWF.

In 2008, the sitting president of UWF resigned to take another position and Judy was nominated to serve for one year as interim president. After review of numerous applicants and interviews with a short list including Dr. Bense, the board of trustees appointed her as interim president effective 1 July 2008, hoping that she could do for the university what she had done for anthropology. The board of trustees has subsequently removed the "interim" from her title and has extended her appointment through 2012.

The J. C. Harrington Medal was established by the SHA in 1981 to recognize a lifetime of contributions to the discipline of historical archaeology focused on scholarship. It remains the highest 
honor bestowed by the society. In reviewing the career of Dr. Judy Bense, it is clear that while her scholarship alone is sufficient to qualify her for this honor, her contribution to the discipline extends well beyond the confines of her research.

Dr. Bense found historical archaeology in downtown Pensacola in the mid-1980s, and she found her professional home in the Society for Historical Archaeology after she joined in 1982 and attended her first conference in 1985 in Boston. She has served the society in a variety of roles, including a term on the board of directors (2001-2003) and as president (2005-2006). She has served on committees, including major and sustained involvement with the SHA Governmental Affairs Committee since 2001. In 2002 the society recognized her contribution to public archaeology with the Award of Merit.

A review of Dr. Bense's extensive record of presented papers and juried publications will reveal two major trajectories of thought during the past three decades: one related to public archaeology and the other related to the archaeology of Spanish colonial Florida. In fact, a closer examination of her contribution to public archaeology will reveal that it is, as has already been mentioned, firmly planted in the historical archaeology of Pensacola and West Florida. Her scholarship over the past three decades has more specifically been focused on the presidios of Pensacola, which, due to their different locations, provide a perfect seriation of Spanish colonial life in Florida. This research has resulted in two edited volumes (Archaeology of Colonial Pensacola 1750-1821 in 1999, and Presidio Santa María de Galve: A Struggle in Survival in 18th-Century Pensacola in 2003) and a thematic volume of Historical Archaeology (2004), Presidios of the North American Spanish Borderlands. Her coffee-table book Unearthing Pensacola, published in 2006, was based on her immensely popular local public radio program of the same name. In addition to these major works in historical archaeology, Dr. Bense also published in 1994 a standard reference in southeastern archaeology, Archaeology of the Southeastern United States: Paleoindian to World War II.

Dr. Bense is currently two-thirds of the way towards completion of a synthetic monograph on the presidios of Pensacola, although her duties as UWF president have put this project on hold. Also on hold is a new research initiative on Mexico's Gulf Coast, where she has begun to investigate the 17th- and 18th-century communities from which the first permanent settlers to Pensacola were drawn. The testing phase of this project, conducted jointly with the Instituto Nacional de Antroplogía e Historia (INAH), showed the presence of extensive, well-preserved remains of this period.

Dr. Bense's contribution to scholarship in historical archaeology is also reflected in the strongly applied graduate program that she built at UWF starting in 1991, and her role as a mentor to many students who are now taking their places in the ranks of successful professionals and research scholars. The applied program at UWF requires a major commitment by students to a serious, local research regime, which Dr. Bense skillfully leveraged by allowing students to be involved in her research and to utilize resulting data for their thesis projects.

It is impossible to talk about Dr. Bense's contribution to scholarship without also talking about her ability in obtaining resources. Through a successful program of grantsmanship which goes back to her first years at UWF, and through successful program development in the Florida legislature, archaeology at UWF has grown from non-existent in 1980 to a program that is today a leader in Spanish colonial and historical archaeology, underwater archaeology, and public archaeology. Due to her efforts, the Department of Anthropology, Institute of Archaeology, and FPAN today employ 14 archaeologists.

Dr. Bense's leadership in historical archaeology and at UWF has also been recognized through her appointment to the Florida Historical Commission beginning in 2002 (chair since 2003), and to the board of the National Center for Preservation, Training, and Technology (chair since 2006). She has also received the Department of the Interior's National Public Service Award (the first ever given for archaeology), the Florida Legislature's Outstanding Performance and Achievement Award, UWF's Distinguished Teaching Award for 1994 and 2001 (selected by students), the Pensacola Pride Award, the Daughters of the American Revolution's National History Award Medal, the Florida Anthropological Society's Ripley P. Bullen Award, the Society for American Archaeology's Presidential Award, the SHA Award of Merit, and the Pace Award for Professional Leadership. 
Since joining SHA in 1982, Dr. Bense has regularly contributed to the program of the annual conference. She has organized and chaired seven symposia and one workshop, and has presented a dozen or so research papers. She has also presented regularly at the meetings of the Southeastern Archaeological Conference and the Society for American Archaeology, as well as at venues such as the World Archaeological Congress and a wide range of regional, specialized, and one-time conferences. She has lent her service to the Society for American Archaeology on their Governmental Affairs Committee, between 1984 and 1999 (chair from 1995); the Southeastern Archaeological Conference as conference chair for the 1984 and 1999 meetings, and on the board of directors (1980-1985 and 1997-1999); the Florida Anthropological Society as second vice president (19921993); and the Florida Archaeological Council on the board of directors (1995-1997), Stewards of Heritage Awards Committee (chair 1994-1995), and Florida Archaeological Week Committee (1993).

By awarding Dr. Judith Ann Bense the 2010 J. C. Harrington Medal in Historical Archaeology at the Amelia Island, Florida conference, the Society for Historical Archaeology acknowledges its gratitude that Dr. Bense chose to leave the business of horses and dogs behind in 1977 and reenter the world of archaeology to which she has been so well suited. In so doing, by sheer ability and perseverance she has built precisely the sort of program of which she had dreamed. As president of UWF and past president of the Society for Historical Archaeology, she was among those dignitaries who this past year welcomed to Pensacola King Juan Carlos and Queen Sophia of Spain on the advent of the 450th anniversary of the first Spanish settlement of Florida in 1559. Judy told them about archaeology. They were fascinated and they were grateful, and, of course, Dr. Bense made certain that UWF students shared in the experience.

\section{Acknowledgements}

The authors would like to thank Della Scott-Ireton and Monica L. Beck for their thoughtful comments on earlier versions of this manuscript.

William B. Lees And Elizabeth D. Benchley 